\title{
Dostojewski w polskiej powojennej refleksji humanistycznej'
}

TAdeusz Sucharski

(Akademia Pomorska w Słupsku)

I.

Dynamicznie rozwijającą się $\mathrm{w}$ dwudziestoleciu międzywojennym polską dostojewskologię na kolejne dwudziestolecie wyhamowała historia i polityka: najpierw okupacja hitlerowska, potem stalinowski komunizm, który zepchnął Fiodora Dostojewskiego (i badania nad jego twórczością) do polskiego naukowego podziemia. W okresie wojny tylko sporadycznie pojawiały się w naszym piśmiennictwie wzmianki poświęcone rosyjskiemu twórcy. I działo się to, oczywiście, jedynie w tekstach powstałych poza krajem objętym okupacją. Trzeba przypomnieć nieobecną właściwie w perspektywie współczesnych badaczy, napisaną po angielsku pracę Mickiewicz, Dostoevsky and Blok (1942) Wacława Lednickiego, pioniera polskiej rusycystyki w Stanach Zjednoczonych.

Refleksja nad miejscem Dostojewskiego w powojennej literaturze i nauce polskiej musi rozpocząć się od przypomnienia, że badania nad spuścizną twórcy Braci Karamazow rozwijały się w dwóch nurtach, których nie sposób poddać podobnej periodyzacji. Stale obecne i wolne od nacisków ideologiczno-politycznych w literaturze emigracyjnej, w kraju podlegały ograniczeniom typowym dla wszystkich państw komunistycznych, szczególnie w epoce stalinizmu. Ryszard Przybylski nie zawahał się jeszcze na początku lat sześćdziesiątych stwierdzić, iż „aktualność Dostojewskiego polega [...] na tym, że jest on w dalszym ciągu «diabłem» dla $\mathrm{XX}$-wiecznego marksizmu"2. Nie stanowiły natomiast istotnej przeszkody, czego

1 Prezentowany szkic jest znacznie rozszerzoną wersją tekstu napisanego wspólnie z Andrzejem de Lazarim, Аостоевский в польской литературе, литературоведении и филофовской мысли с 70-х лет XX века, в: Аостоевский. Материальь и исследования, т. 20, Санкт-Петербург 2014, с. 25-43.

2 Mówi Ryszard Przybylski, „Współczesność” 1964, nr 23, s. 7. 
dowodzi polska dostojewskologia emigracyjna, przekonania polityczne pisarza, które jeszcze w wieku XIX zamykały mu „drogę do Polski”3. Młoda Polska wybaczyła autorowi Biesów jego antypolskie fobie, a dwudziestolecie dowiodło, że polski pisarz i czytelnik potrafią docenić wartość artystyczną i głębię psychologiczną dzieł twórcy, abstrahując od jego nieczęstych w istocie majaczeń szowinistycznych. Nie znaczy to wszakże, że ów problem zniknął zupełnie $\mathrm{z}$ horyzontu badawczego, zmienił się jednak sposób jego oglądu.

Kierunek refleksji nad polonofobią autora Braci Karamazow, przenosząc punkt ciężkości na grunt ogólnoludzki, wytyczył przed wojną Jerzy Stempowski w aktualnym do dziś eseju Polacy w powieściach Dostojerwskiego. Uznał w nim, że źródeł niechęci pisarza do Polaków należy szukać w podejmowaniu przez polskich zesłańców poznanych na omskiej katordze prób racjonalnego tłumaczenia męki. A męka, zgodnie $z$ rosyjskim ludowym przekonaniem, jako immanentna część ludzkiego losu musi pozostać niewytłumaczalna. Taka dumna i niezrozumiała postawa oddzielała Polaków zasadniczo od katorżników rosyjskich. Nie wszystkich jednak przekonała ta interpretacja. Niemal idealnie w „polską” postawę wpisał się Wacław Grubiński, także ofiara sowiecko-rosyjskich represji. Patrzył on na twórczość rosyjskiego pisarza, bliski w tym Josephowi Conradowi, oczami racjonalisty zachodnioeuropejskiego, odrzucającego rosyjską „,histerię”", w którą włączal też filozoficzny irracjonalizm. Oskarżenia Dostojewskiego o polonofobię, a w konsekwencji niechęć do jego twórczości, pojawią się również w Dzienniku Jana Lechonia, w Szkicach piórkiem Andrzeja Bobkowskiego, w esejach Władysława Folkierskiego i Lucjana Lewittera.

Problem postawy Dostojewskiego wobec Polaków nie dawał (i nie daje) spokoju także współczesnym krajowym badaczom twórczości. Małgorzata Świderska, sięgając po instrumenty imagologii, „umiędzynarodowiła” problem zamknięty do tej pory w granicach polskiej dostojewskologii. Opublikowała w języku niemieckim książkę, w której sposób przedstawienia Polaków przez Dostojewskiego przeanalizowała $\mathrm{z}$ „wyobrażeniowego" punktu widzenia. Marek Wedemann z kolei prześledził najwcześniejszą polską recepcję autora Biednych ludzi, w półwieczu od pojawienia się jego debiutanckiej powieści aż po koniec wieku XIX, kiedy ujawniło się silne prodostojewskie stanowisko wielu twórców młodopolskich. Autor nie udziela wprost odpowiedzi na postawione w tytule książki prowokacyjne pytanie:

3 J. Kulczycka-Saloni, Dostojewski w Polsce, „Miesięcznik Literacki” 1972, nr 3, s. 41.

4 W. Grubiński, Polscy „panowie” Dostojewskiego, w: idem, O literaturze i literatach, Londyn 1948, s. 101-103.

5 M. Świderska, Studien zur literaturwissenschaftlichen Imagologie. Das literarische Werk F.M. Dostoevskijs aus imagologischer Sicht mit besonderer Berücksichtigung der Darstellung Polens, München 2001; autorka kontynuowała badania, zajmując się miejscem ekfrazy w pismach rosyjskiego twórcy: eadem, Ekfraza wpowieści „Idiota” Fiodora M. Dostojewskiego jako sposób konstruowania kulturowej obcości, „Slavia Orientalis”2003, nr 2. 
„polonofil czy polakożerca?”, dokonuje wszakże rewizji przekonań o zasadniczo negatywnym polskim nastawieniu. Pisarz rosyjski przez polską opinię był przyjmowany pozytywnie jako humanitarysta, ale także jako ofiara caratu, a więc trochę jakby „swój”. Decydujący wpływ na taką specyficzną recepcję miało pośrednictwo rosyjskiej krytyki liberalnej ${ }^{6}$.

\section{2.}

Emigracja polska, w istotnym stopniu spadkobierczyni literatury międzywojennej, kontynuowała zainteresowanie rosyjskim geniuszem. To właśnie w Londynie powstała pierwsza polska monografia Dostojewskiego autorstwa Stanisława Mackiewicza (Cata). Jej fragmenty zaczęto drukować w „Wiadomościach” londyńskich w 1950 roku, wcześniej jednak książka opublikowana została w wersji angielskojęzycznej (Dostoevsky, I947). W Anglii przyjęto ją z dużym uznaniem7. Można zasadnie przypuszczać, że polski twórca wspomagał się materiałami z pracy Leonida Grossmana Жизнь и труды Ф. М. Аостоевского ${ }^{8}$ z 1935 roku, wykorzystanymi później przez badacza w zbeletryzowanej biografii autora Idioty, której polskie tłumaczenie ukazało się w 1968 roku$^{9}$. Wydaje się, że z tych źródeł właśnie zaczerpnął Mackiewicz wiele nieznanych wcześniej polskim badaczom faktów z życia pisarza. Pierwsze próby wydania książki w Polsce stalinowskiej zakończyły się niepowodzeniem, lecz już w poodwilżowym roku 1957, po powrocie Mackiewicza do Polski, monografia trafiła także do czytelnika krajowego. Znalazł on w niej zaskakujący portret wielkiego pisarza, ale również bardzo małego człowieka. Mackiewicz bowiem skupił się na biografii, wkomponowując ją w szeroką panoramę Rosji Mikołaja I i Aleksandra II. W żywej narracji o rosyjskim twórcy autor nie ukrywa swoich uczuć, akcentuje śmieszności i grzechy pisarza, nie wstrzymuje się nawet przed powtarzaniem plotek, w tym tej najgorszej (za Strachowem) o gwałcie na dziewczynce. Ale jednocześnie ujawnia niezwykłe tajemnice geniuszu, znajduje bodaj najpiękniejsze formuły językowe dla twórczości pisarza, który „chciał być pisarzem rosyjskim, [a] przez swój związek

6 M. Wedemann, Polonofil czy polakożerca? Fiodor Dostojewski w piśmiennictwie polskim lat 1847-1897, Poznań 2010. Problem polonofobii rosyjskiego pisarza próbował również naświetlić na nowo Jacek Uglik (idem, Polacy w powieściach i publicystyce Dostojewskiego, „Przegląd Powszechny” 2004, nr 11; idem, Обpas поляков в романах и публиистике Аостоевского, „Toronto Slavic Quarterly” 2011, nr 37).

7 S. Mackiewicz, Rzecz o „Dostojewskim” w „Wiadomościach”, „Wiadomości” 1950, nr 34 (229), s. 4.

8 А.П. Гроссман, Жизнь и труды Ф.М. Аостоевского: биография в датах и документах, Москва- Аенинграa 1935.

9 L. Grossman, Dostojewski, tłum. S. Pollak, Warszawa 1968. 
z Ewangelią stał się pisarzem uniwersalistycznym" ${ }^{\text {Io }}$. Proponuje nowatorskie odczytanie utworów (Sioto Stiepanczykowo). I otwiera nowe perspektywy przed ówczesną polską refleksją nad twórczością Dostojewskiego. Monografia Mackiewicza to książka bardzo nierówna, obok fragmentów niemal prostackich pojawiają się w niej ustępy odkrywcze, czego w pełni dowodzi podobieństwo prób interpretacyjnych z późniejszymi odczytaniami Josifa Brodskiego ${ }^{\text {II }}$. Obaj widzą w Dostojewskim pisarza walczącego o duszę człowieka. Wysoko ocenił książkę Cata, tę w wersji angielskiej, Stempowski ${ }^{\mathrm{I2}}$, dzieląc się kilkoma refleksjami nad techniką powieściową autora Idioty. Dostrzegał w niej nawiązanie do tradycji powieści ludowej, której wielkim twórcą był Daniel Defoe, po nim Eugène Sue ${ }^{\mathrm{I}}$. Być może uwaga ta wiązała się z przenikliwą tezą Mackiewicza, że Dostojewski w niezwykły sposób umiał połączyć w powieściach poetykę romansu brukowego z poetyką ewangelicznej paraboli.

Refleksja nad książką Mackiewicza, publicysty i pisarza przecież, zmusza wręcz do zwrócenia uwagi na szczególne miejsce, jakie w namyśle nad twórczością Dostojewskiego zajmują opinie jego „sukcesorów” literackich ${ }^{\mathrm{I}}$. Trzeba powiedzieć więcej: bez ich uwzględnienia nasza dostojewskologia okazałaby się znacznie uboższa. W dwudziestoleciu międzywojennym najlepsze prace o twórcy Biesórw powstały nie w gabinetach badaczy literatury, ale na biurkach pisarskich Andrzeja Struga i Teodora Parnickiego. Po wojnie pisali o nim niemal wszyscy wielcy twórcy emigracyjni. Ważną książkę w kraju wydał Adolf Rudnicki ${ }^{15}$, wcześniej pojawił się esej Jarosława Iwaszkiewicza (portret pisarza, połączony z lekturą Idioty ${ }^{\mathrm{I}}$ ), a Bogdan Wojdowski opublikował szkic Mit Szigalewa ${ }^{17}$, inspirowany Camusowską adaptacją Biesórw, w którym podkreślał polityczną przenikliwość pisarza w przedstawieniu rewolucji, co w literaturze krajowej owych czasów dowodziło sporej odwagi.

Trudno właściwie wskazać w polskim piśmiennictwie emigracyjnym ważnego twórcę, który by nie odnosił się w swoich tekstach do Dostojewskiego. Pisarz

10 S. Mackiewicz, Dostojewski, Warszawa 1957, s. 79.

11 J. Brodski, Dlaczego Kundera myli się co do Dostojewskiego?, tłum. A. Zagajewski, „Zeszyty Literackie” 1996, nr 3, s. 102.

12 J. Stempowski, Stanistaw Mackiewicz o Dostojewskim oraz kilka uwag o biografiach literackich, w: idem, Klimat życia i klimat literatury. 1948-1967, wybór i oprac. J. Timoszewicz, Warszawa 1988, s. 34.

13 Stanisław Baczyński w książce napisanej na początku lat trzydziestych zauważył, że Dostojewski „przywrócił zbrodni prawo obywatelstwa w literaturze «poważnej»" (idem, Literatura w ZSRR, Kraków-Warszawa 1932 , s. 45).

14 Uwaga ta nie odnosi się tylko do pisarzy polskich, wspomnieć trzeba znakomite eseje André Gide’a, Tomasza Manna, Hermanna Hessego czy - najbardziej aktualne - Alberta Camusa.

15 A. Rudnicki, Sto lat temu umart Dostojewski, Warszawa 1984.

16 J. Iwaszkiewicz, Petersburg, Warszawa 1976.

17 B. Wojdowski, Mit Szigalewa, Warszawa 1982. 
ten pojawia się, w różny zresztą sposób, w esejach Gustawa Herlinga-Grudzińskiego, Czesława Miłosza, Aleksandra Wata, Józefa Czapskiego, Józefa Wittlina, w dziennikach Jana Lechonia, Witolda Gombrowicza, Andrzeja Bobkowskiego, Herlinga-Grudzińskiego, w sfabularyzowanych relacjach polskich więźniów GUŁagu - Stanisława Swianiewicza, Wacława Grubińskiego, które w istotny sposób odnosily się do Zapisków z martwego domu ${ }^{\mathrm{I8}}$, a przede wszystkim zaistniały w Innym świecie. Herling-Grudziński był bowiem bez wątpienia tym polskim pisarzem, który najgłębiej sięgnął do twórczości Dostojewskiego. Źródeł owego zainteresowania szukać należy w doświadczeniu biograficznym polskiego twórcy. W sowieckim łagrze przeczytał Zapiski z martwego domu, w których odnalazł wizję Rosji jako wiecznego „Martwego Domu”, i w odniesieniu do tej książki napisał swoje dzieło o „innym świecie” obozu ${ }^{\text {19 }}$. Utworowi o duchowej degradacji przeciwstawił Herling Inny świat, który pokazuje duchowy rozwój i zwycięstwo człowieka nad systemem, nad ludzką słabością i fizycznością. Paradoksalne jest to, że Zapiski z martwego domu, wyraz fatalistycznego determinizmu rosyjskiego, wyzwoliły w polskim pisarzu heroistyczne spojrzenie na los, historię i miejsce, jakie zajmuje w niej człowiek.

Do problemów, które wtargnęły do świadomości w łagrze, powracał Herling w całej twórczości. W opowiadaniach (Skrzydta ottarza), w esejach (Drugie Przyjscie, Upiory rewolucji) polski pisarz, w żywym dialogu z wielkim Rosjaninem, szukał odpowiedzi na pytanie o istotę człowieczeństwa. Próbował rozwiązać zagadkę Dostojewskiego, z jednakową uwagą analizując jego życie i twórczość, najczęściej jedno drugim wspierając. Ukazywał transformację osobistych doświadczeń Dostojewskiego w wielką literaturę. Unaoczniał jego rozdarcie, poddawanie się pokusie zwątpienia, ale i fanatyzmu, ateizmu i sekciarstwa. Widział w nim bowiem Herling pisarza religijnego, który poddawał się nieustannemu wątpieniu i uparcie powracał do „przeklętych problemów”.

Znaczenie Dostojewskiego w twórczości Herlinga-Grudzińskiego okazało się na tyle istotne, że problemowi temu Tadeusz Sucharski poświęcił całą monografię Dostojerwski Herlinga-Grudzińskiego, w której uwaga skoncentrowana jest na przebadaniu „przestrzeni rezonansu” (używając terminu Władimira Toporowa) w dziełach Grudzińskiego, ujawniającej wielostronne powiązania z twórczością i osobą rosyjskiego pisarza. Wskazując podobieństwo ich doświadczenia katorżno-obozowego, wspólną im formułę „poszukiwania człowieka w człowieku”, autor stara się wskazać wspólną płaszczyznę metafizyczną, podobne wysiłki znalezienia

18 W polskim tłumaczeniu opublikowane pod niewłaściwym tytułem Wspomnienia $z$ domu umartych; zob. R. Zimand, Martwy dom żywych ludzi, w: idem, Czas normalizacji. Szkice czwarte, Londyn 1989, s. 115$-116$.

19 Zob. T. Sucharski, Dostojewski Herlinga-Grudzińskiego, Lublin 2002. 
wyjścia z zaułka pozbawionego transcendencji. Próbuje także przekonać, że nie ma w literaturze polskiej drugiego utworu, w którym przestrzeń intertekstualna byłaby jednocześnie miejscem artykulacji narodowych historiozofii.

W tekstach poświęconych Dostojewskiemu Sucharski zwraca głównie uwagę na inspirujące znaczenie jego dziedzictwa dla polskich pisarzy. Nie interesuje go natomiast kwestia wpływu; nie lekceważąc bynajmniej Stoffgeschichte, próbuje wychwycić inspiracyjne bądź inspiracyjno-polemiczne formy obecności Dostojewskiego w dziełach polskich, znaleźć ideowe płaszczyzny sporu. Poza Herlingiem będą to także pisma Miłosza i Gombrowicza ${ }^{20}$.

Miłosza do Dostojewskiego prowadziła skomplikowana droga. Nie stworzył poeta-profesor książki o twórcy Biesów, obawiał się bowiem, że byłaby to „książka nieufności”, której źródło stanowił „żarliwy rosyjski millenaryzm i mesjanizm” ${ }^{\text {2I }}$ pisarza. Niechęci towarzyszył wszakże podziw dla obrony przez pisarza rosyjskiego wiary w Chrystusa ewangelicznego, negowanego przez inteligencję rosyjską "zainfekowaną" przejętym z Zachodu światopoglądem naukowym. Kwintesencji myśli Dostojewskiego szukał Miłosz w Zapiskach z podziemia i w Legendzie o Wielkim Inkwizytorze. Jego refleksję zapoczątkowały eseje w Ziemi Ulro, w których podją próbę opisu relacji między twórczością pisarza i zachodnią wyobraźnią religijną. Wykazał w dziele Dostojewskiego antynomie myśli europejskiej wieku rozumu, zaakcentował także nacjonalistyczne mielizny jego myśli. Sprzeciw wobec prób uczłowieczenia Boga łączył bowiem twórca Biesów z mesjanistyczną wiarą w rosyjskiego boga ${ }^{22}$. Autor Ziemi Ulro zauważył wszakże podobną u Mickiewicza i Dostojewskiego mesjanistyczną skłonność do narodowej herezji: Konrad z Dziadów, przyrównując Boga do cara, staje się bliski Szatowowi, który wierzy w Rosję, nie wierzy w Boga. Ale w Mickiewiczowskiej teodycei znajdował Miłosz odpowiedź na niebezpieczeństwo poddania się logice myśli Iwana Karamazowa, której konsekwencją byłoby uznanie wszechświata za absurd. Ważnym uzupełnieniem sądów poety o twórcy Biesów okazały się jego wypowiedzi publicystyczne ${ }^{23}$. Podkreślał w nich, że oba mesjanizmy, polski i rosyjski,

20 Idem, „Zbrodnia i kara” w literaturze polskiej - recepcja, polemika, inspiracja, w: Dostojewski i inni literatura, idee, polityka: ksiega jubileuszowa dedykowana profesorowi Andrzejowi de Lazariemu, red. T. Sucharski przy współpracy M. Michalskiej-Suchanek, Katowice 2016, s. 155-208.

21 Cz. Miłosz, Abecadto Mitosza, Kraków 1997, s. 99. Książkę będącą wyborem z pism Miłosza stworzyli jego badacze: Cz. Miłosz, Rosja. Widzenia transoceaniczne, t. 1, Dostojewski - nasz wspótczesny, wybór B. Toruńczyk i M. Wójciak, oprac. B. Toruńczyk, wstęp C. Cavangh, Warszawa 2010.

22 T. Sucharski, Mitosz i „herezje” Dostojewskiego, w: „Pótnocna strona” Mitosza, red. M. Czermińska i K. Szalewska, Gdańsk 2011, s. 215-228.

23 Zob. wypowiedzi zebrane w cytowanym wyżej tomie: Cz. Miłosz, Rosja. Widzenia transoceaniczne, t. 1, Dostojewski - nasz wspótczesny: Dostojewski dzisiaj; Źródta leża w zachodniej Europie. Wywiad. (Czestaw Mitosz odpowiada na pytania Zbigniewa Podgórca); Dostojewski; Dostojewski badat choroby ducha. Wywiad. $Z$ Czestawem Mitoszem rozmawiaja C. Gawryś i J. Majewski; Diagnoza nieostateczna. Rozmowa o rosyjskiej historii, literaturze i polityce. $Z$ Czestawem Mitoszem rozmawia S. Frotow. 
były konsekwencją kolektywnej natury obu narodów. Niezwykle ciekawe jest również Miłoszowskie rozumienie rewolucji, której prorokiem okrzyknięto Dostojewskiego. Poeta akcentuje jej aspekt religijny, czyli dokonanie wyboru człowieka-boga w miejsce Boga-człowieka. Wyjaśnia także paradoks uniwersalności pisarza zamkniętego przecież w wewnętrznych problemach rosyjskich. Według Miłosza wynika to ze specyfiki sytuacji dziewiętnastowiecznej Rosji, która - opóźniona wobec Europy skupiła w sobie problemy znane na Zachodzie od wieków.

Niezwykle inspirujące, może nawet kontrowersyjne rozważania Miłosza na temat Dostojewskiego wywołały żywe komentarze. Pierwszy pisał o nich Lucjan Suchanek $^{24}$, który wysoko ocenił dostrzeżony przez Miłosza związek twórcy Zbrodni i kary ze Swedenborgiem. Elżbieta Mikiciuk w walce polskiego poety z „przeklętymi pytaniami” Dostojewskiego wyczytała niezgodę na istniejący w świecie porządek, dla którego przeciwwagę znajduje poeta w wierze w apokatastazę 25 . Z kolei Sucharski podkreślał ambiwalentny stosunek Miłosza do „herezji” Dostojewskiego. Bliska poecie była herezja teologiczna, wysiłki „przywrócenia” Boga sprzed oświeceniowego przełomu, niechęć wzbudzało kacerstwo mesjanistyczno-nacjonalistyczne twórcy Biesów, czyli próba „rusyfikacji” Boga.

Zupełnie inne problemy poruszały Gombrowicza. „Grę” z Dostojewskim podjąl już w debiutanckim Pamiętniku z okresu dojrzerwania ${ }^{26}$. Polski pisarz bowiem właśnie bardziej grał z rosyjskim twórcą, niż o nim pisał. Wszelako w jednym z dziennikowych zapisków przedstawił swoje rozumienie postaci „mgławicowego” Raskolnikowa, wpisując go w koncepcję „kościoła międzyludzkiego” i obowiązującego w nim „zwierciadlanego sumienia”. Temu „sumieniu” poddaje się bohater świadomy spodziewanej reakcji „współczłonków” owego „kościoła” ${ }^{2}$. Pogląd ten wywołał sprzeciw Herlinga, który przekonywał, że Zbrodni i kary nie wolno czytać jako historii adaptacji przestępcy do kodeksów postępowania przyjętych przez zbiorowość, ale jako dzieło „o świadomej potrzebie zaczepienia swojego «ja» o wartość absolutną i niezmienną”28. Herling kwestionuje „samowystarczalność międzyludzką”, wierząc, że istnieje sankcja metafizyczna, którą Gombrowicz odrzucał ${ }^{29}$.

24 L. Suchanek, Fiodor Dostojewski w ocenie Czestawa Mitosza, w: Fiodor Dostojewski w setną rocznice śmierci, red. M. Bobran, Rzeszów 1985, s. 60-68.

25 E. Mikiciuk, Dostojewski Mitosza, w: Idea i komunikacja w jezyku i kulturze rosyjskiej, red. A. Dudek, Kraków 2011, s. 475-484.

26 J. Jarzębski, Gra w Gombrowicza, Warszawa 1982, s. 23-88.

27 W. Gombrowicz, Dziennik 1957-1961, Kraków 1988, s. 199.

28 G. Herling-Grudziński, Dwugtos o sumieniu Raskolnikowa, w: idem, Godzina cieni. Eseje, wybór i oprac. Z. Kudelski, Kraków 1991, s. 88-89.

29 W. Bolecki, Ciemny Staw. Trzy szkice do portretu, Warszawa 1991, s. 40; T. Sucharski, Dostojewski HerlingaGrudzińskiego, s. 162-163. 
3.

Do oficjalnej kultury PRL-u Dostojewski wrócił pod koniec lat pięćdziesiątych wraz z rehabilitacją literatury metafizycznej, eksperymentalnej. Ale aż do upadku komunizmu polscy dostojewskolodzy musieli zmagać się z naciskami cenzorskimi, ze świadomością możliwych ingerencji. Mimo to najważniejsze osiągnięcia trzydziestolecia 1957-1989 w zakresie rozważań nad rosyjskim geniuszem, które zebrał i podsumował Jerzy Kapuścik ${ }^{30}$, z pewnością pozostaną na zawsze w polskiej humanistyce. Zainicjowało je krajowe wydanie Mackiewiczowskiej monografii.

Publikacji książki Mackiewicza towarzyszyły dyskusje w odwilżowej prasie kulturalno-literackiej („Po prostu”, później „Współczesność”). W refleksji nad twórczością Dostojewskiego istotną rolę odegrał miesięcznik „Znak”. Wypowiedzi publicystyczne inspirowane były pojawiającymi się pracami naukowymi poświęconymi miejscu autora Idioty w świecie dziewiętnastowiecznych idei filozoficznych ${ }^{3 \mathrm{I}}$, przede wszystkim tekstami Andrzeja Walickiego i Ryszarda Przybylskiego. Ważne były także krajowe inscenizacje powieści Dostojewskiego i sowiecka ekranizacja Idioty Iwana Pyrjewa. W jej recenzji Ernest Bryll oburzał się na sprowadzanie pisarza do roli krytyka moralności mieszczańskiej i „kultu pieniądza" ${ }^{2}$. Poeta-recenzent sprzeciwił się, choć nie wprost, odzieraniu Dostojewskiego z głębi metafizycznej, co było ujęciem typowym dla epoki wulgarnego marksizmu. W „Znaku” rozpoczął swoją długą przygodę z rosyjskim pisarzem Zbigniew Żakiewicz ${ }^{33}$. Tu również publikował ks. Tomasz Podziawo, sprowokowany tezami Żakiewicza i Walickiego. Jego szkic o religijności Dostojewskiego był jednym $z$ najwcześniejszych tekstów w PRL-u na ten temat ${ }^{34}$, w dodatku napisanym przez księdza ${ }^{35}$.

Prace Walickiego i Przybylskiego stały się przełomem w polskich badaniach nad twórczością rosyjskiego pisarza. Walicki, historyk idei, nie napisał co prawda oddzielnej książki o Dostojewskim, ale w swoich pracach wielokrotnie powracał

30 J. Kapuścik, Próba syntezy. Fiodor Dostojewski na warsztacie polskich badaczy w ostatnim trzydziestoleciu, „Przegląd Humanistyczny” 1994, nr 4 (325), s. 125-141.

31 Z. Żakiewicz, Dostojewski na tle prądów filozoficznych epoki, „Znak” 1960, nr 7-8, s. 1019-1025. W szkicu tym autor nawiązał do nowo wówczas wydanej książki Andrzeja Walickiego Osobowość a historia: studia $z$ dziejów literatury i myśli rosyjskiej (Kraków 1959).

32 E. Bryll, Z Dostojewskim polemiki, „Współczesność” 1959, nr 4, s. 5.

33 Z. Żakiewicz, W'świecie pozornej wolności, „Znak” 1959, nr 5, s. 619-627.

34 Wcześniej pisali o tym Jan Dobraczyński (Poszukiwania nadcztowieczeństwa, w: idem, Wielkośc i świętość. Eseje, Warszawa 1958) oraz Aleksander Rogalski (Dostojewski - Homo religiosus, w: idem, Profile i preteksty, Warszawa 1958).

35 T. Podziawo, Dostojewski (Uwagi dyskusyjne), „Znak” 1959, nr 12, s. 1590-1594; idem, Czy Dostojewski byt filozofem?, „Znak” 1960, nr 73-74, s. 1026-1028. 
64

do jego myśli. W publikacji Osobowość a historia ${ }^{36}$ pomieścił niezwykle istotny szkic Dostojewski i idea wolności, natomiast w pracy poświęconej słowianofilskiemu nurtowi w myśli rosyjskiej poddał analizie fundamentalną dla historiozofii twórcy Biesów ideę poczwienniczestwa ${ }^{37}$, którą po latach rozwinie Andrzej de Lazari. W książce tej Walicki przedstawił Dostojewskiego jako głębokiego myśliciela, badacza „dialektyki własnej woli” - prowadzącej od osobistego zniewolenia Kiriłłowa i Raskolnikowa do totalitarnej rzeczywistości Szigalewa i Wielkiego Inkwizytora.

Równocześnie z pracą Walickiego o przemianach rosyjskiego słowianofilstwa do czytelnika trafiła najlepsza jak do tej pory polska monografia twórczości rosyjskiego geniusza - Dostojerwski i „przeklęte problemy”. Określenie „monografia” skrupulatnemu czytelnikowi może się wydać przesadzone, ponieważ Przybylski objął w niej twórczość „tylko” od Biednych ludzi do Zbrodni i kary, zabrakło więc w pracy miejsca na refleksję nad największymi dziełami Dostojewskiego. Ale jej znaczenie, nawet ze współczesnej perspektywy, wydaje się absolutnie fundamentalne; książka Przybylskiego „radykalnie zmieniła sytuację" ${ }^{3^{8}} \mathrm{w}$ polskim oglądzie spuścizny twórcy Notatek z podziemia. Niezwykle mocno wybrzmiała podkreślana przez badacza teza, że autor Zbrodni i kary „był jedynym pisarzem XIX wieku, który z taką determinacją bronił idei chrześcijańskiej harmonii świata"39. Książka Przybylskiego była reakcją na najbardziej rozpowszechnione wówczas (i „prostackie”) metody badania Dostojewskiego: albo „naiwny biografizm”, dla którego jedynym kluczem do twórczości było szukanie źródeł w życiu pisarza, albo „naiwny socjologizm"40, który tłumaczył wszystko represyjnym system państwa carów. Przybylski patrzy na twórcę Notatek z podziemia jako na pisarza wyrastającego z romantyzmu, poszukującego szans moralnej reedukacji człowieka. Nie tylko wpisuje owe poszukiwania w antynomie człowieka współczesnego, ale w dziele Dostojewskiego szuka ,genealogii naszej współczesności” ${ }^{4}$. Akcentuje przede wszystkim problemy religijne i etyczne, podkreśla fundamentalny wpływ Aleksandra Puszkina, George'a Byrona, Friedricha Schillera, Michaiła Lermontowa, czyta Dostojewskiego w kontekście dziewiętnastowiecznej filozofii europejskiej: młodoheglistów (Max Stirner, Ludwig Feuerbach), Jeremy'ego Benthama, Johna Stuarta Milla, socjalizmu utopijnego, podkreśla wreszcie istotne znaczenie tradycji rosyjskiej myśli religijnej,

36 A. Walicki, Osobowość a historia...

37 Idem, W kregu konserwatywnej utopii. Struktura i przemiany rosyjskiego stowianofilstwa, Warszawa 1964.

38 Mówi Ryszard Przybylski.

39 Ibidem.

40 T. Burek, Horyzont Dostojewskiego, „Twórczość” 1965, nr 10, s. 115.

41 R. Przybylski, Dostojewski i przeklęte problemy. Od „Biednych ludzi” do „Zbrodni i kary”, Warszawa 1964, s. 32 . 
i przywołuje dziedzictwo Niła Sorskiego, Tichona Zadońskiego, Paisjusza Wieliczkowskiego, a także prawosławnej patrystyki Pseudo-Dionizego Areopagity czy Maksyma Wyznawcy. Historia idei przeplata się z hermeneutyką, ze sztuką interpretacji. Dyskurs naukowy Przybylskiego ociera się o eseistyczną formułę, co pozwala umiejscowić monografię w pobliżu literatury pięknej.

W zaistnieniu książek Walickiego i Przybylskiego widzieć trzeba wielkie wydarzenia intelektualne, które pod wieloma względami determinowało dalsze polskie studia nad rosyjską myślą i literaturą, w tym oczywiście nad dziełem Dostojewskiego. Można by powiedzieć, parafrazując twórcę Biednych ludzi, że wszyscy współcześni polscy badacze jego twórczości „wyszli spod płaszcza” Walickiego i Przybylskiego, pozostając rzecz jasna także pod „okryciem” Bachtina.

We wstępie do książki o „przeklętych problemach” Przybylski obiecał drugi tom, ale z powodu trudności z cenzurą nie mógł dotrzymać słowa. Próbował uzupełnić te dojmujące braki wielkim rozdziałem o Dostojewskim w dwutomowej Historii literatury rosyjskiej pod redakcją Mariana Jakóbca (197I), a także szkicami poświęconymi „przeklętym problemom”, personifikowanym przez wykreowanych bohaterów (Stawrogin, Kiriłłow). W roku 1972 w „Tekstach” opublikował Przybylski artykuł Śmierć Stawrogina (co spowodowało interwencję ambasady ZSRR), który dwadzieścia cztery lata później wraz z esejem Marii Janion Czy Stawrogin jest postacia tragiczna? trafil do książki Sprawa Stawrogina ${ }^{42}$. Są to dwie najbardziej znane, ale i wzajemnie się wykluczające polskie interpretacje osobowości Stawrogina. Dla Przybylskiego Stawrogin to rosyjski Don Juan, zmieniający kolejno swoje światopoglądy, który nie jest w stanie uwierzyć w żadną ideę. Nie kryjąc niechęci, eseista nazywa go „zblazowanym, pubertalnym kontestatorem”43 i dowodzi, że Dostojewski personifikuje w bohaterze Biesów typowe rosyjskie życie ideowe ludzi sprzedających wolność pustce. Trochę podobnie, choć mniej kategorycznie konstatował Stefan Chwin, który w kreacji Stawrogina próbował odnaleźć „diagnozę i ostrzeżenie" ${ }^{44}$ pisarza przed nowo kształtującą się rzeczywistością duchową. Dla Marii Janion natomiast bohater Biesów to immoralista, który ujawnia „nowożytną jakość tragizmu". Odszedłszy od Boga, pochyla się pod ciężarem wolności i zła, odczuwając doświadczenie „pustej transcendencji”, a także bolesnego, choć „pustego poczucia winy" ${ }^{35}$. Trzeba wspomnieć cenną próbę zupełnie nowego spojrzenia na Stawrogina, zwłaszcza w kontekście jego samobójstwa, którą zaproponowała

42 M. Janion, R. Przybylski, Sprawa Stawrogina, posł. T. Komendant, Warszawa 1996.

43 R. Przybylski, Stawrogin, „Teksty” 1972, nr 4, s. 37.

44 Dlaczego Kain nie chce „stać się dzieckiem”? Rozmowa o „Biesach” Dostojewskiego [wypowiedzi w dyskusji], w: Dzieci, wybór, oprac. i red. M. Janion i S. Chwin, t. 2, Gdańsk 1988, s. 97. W tym samym tomie pomieszczony został esej Stefana Chwina Stawrogin i dziecko (s. 40-71).

45 M. Janion, Czy Stawrogin jest postacia tragiczną?, w: Dzieci, t. 2, s. 78. 
Halina Chałacińska-Wiertelak. Jej zdaniem w samobójczych rekwizytach (sznur, młotek i wielki gwóźdź), uznawanych za przedmioty bluźnierstwa, można widzieć, paradoksalnie, instrumenty służące „dla realizacji świętej tajemnicy, niemożliwej do słownego wypowiedzenia" ${ }^{\prime 6}$. W ten sposób Biesy urastają do wielkiej metafory narodzenia najważniejszego symbolu chrześcijaństwa, czyli krzyża

Kolejną po znakomitej książce Przybylskiego odważną monografię twórczości, ale także życia Dostojewskiego opublikował filozof i poeta Bohdan Urbankowski. I zatytułował ją Dostojerwski-dramat humanizmórw. Tytuł całości jest w istocie powtórzeniem tytułu jednego z rozdziałów części książki poświęconej refleksji nad wzajemnymi relacjami między sztuką i filozofią Dostojewskiego. Można by więc w tym szukać jakichś autorskich sugestii aksjologicznych, zaakcentowania, i słusznie, ważności tego rozdziału. W pierwszej części książki autor zająl się bowiem analizą związków między życiem i twórczością, skupił uwagę na erotycznych aspektach życia, poszerzając grono dramatis personae ukazane przez poprzedników. W życiu osobistym pisarza, w niedowiedzionej zbrodni, dystansując się wszelako od „literackiego plotkarstwa”, dopatruje się jednak „artystycznego materiału”47. Ale wartość tej książki ujawnia się w dalszych partiach, które dowodzą niemałej sztuki analizy strukturalnej Urbankowskiego. Dzieli się on spostrzeżeniami nad sposobem tworzenia „nadpowieści”, czyli „dzieła wyższego rzędu, zawierającego kilka na raz światów” ${ }^{4}$. Sztukę pisarska Dostojewskiego nazywa „techniką nakładanych klisz" ${ }^{49}$, przy okazji wspomina o polifonii, pomija jednak nazwisko Bachtina(!). Najcenniejsze fragmenty książki poświęca autor refleksji nad światopoglądem Dostojewskiego, w czym wyraźnie ujawnia się wpływ Andrzeja Walickiego, naukowego mentora. Rekonstruuje myśl pisarza na podstawie całej jego twórczości - i artystycznej, i publicystycznej, przy czym sięga także do fragmentów nietłumaczonych na język polski. Światopogląd Dostojewskiego, jego koncepcję alienacji człowieka (przede wszystkim ontologicznej) jako konsekwencji „odpadnięcia świata od Boga" "5o, interpretuje w kontekście filozofii niemieckiej (głównie Marksa i Feuerbacha). Według Urbankowskiego tragizm bytu zdeterminowany jest rozdarciem człowieka między światem Bożym i światem ziemskim, a Dostojewski szuka szans przezwyciężenia alienacji, możliwości reintegracji w humanizmie. „Humanizm” w tytule książki przyjmuje formę liczby mnogiej, ponieważ w twórczości autora

46 H. Chałacińska-Wiertelak, Ставрогин - „сердиевина” романа Ф.М. Аостоевского „Бесь”, w: еаdет, Культурный код в литературном произведении, Poznań 2003, s. 88 (tłum. T. S.).

47 B. Urbankowski, Dostojewski - dramat humanizmów, Warszawa 1978, s. 99.

48 Ibidem, s. 100.

49 Ibidem, s. 117.

50 Ibidem, s. 171. 
Idioty widzi Urbankowski pole walki między trzema modelami humanizmów: utopijnego, prometejskiego (romantycznego) i chrześcijańskiego. Ale w żadnym $\mathrm{z}$ nich nie znajdzie oczekiwanych rozwiązań. Dlatego też w ujęciu badacza Dostojewski to chrześcijanin humanista, który ponosi porażkę filozoficzną, zwyciężając wszakże na gruncie artystycznym.

Na początku lat siedemdziesiątych XX wieku w polskiej dostojewskologii z całą siłą ujawniły się nowatorskie metody analizy. Reprezentowały je Halina Brzoza i Halina Chałacińska-Wiertelak. Pierwsza z nich, sięgając po instrumenty metody strukturalnej ${ }^{j \mathrm{I}}$, próbuje wniknąć w zasady ujawniania immanentnego światopoglądu i wewnętrznej estetyki powieści Dostojewskiego - odkryć „,zasadę zasad”, nie tylko obecną we wszystkich utworach pisarza, ale wręcz scalającą ich substancję. W poetyce widzi nośnik „systemu światopoglądowego dzieła”22. Podejmuje krytyczną dyskusję z koncepcją „powieści polifonicznej” Michaiła Bachtina, z jego tezą, że model strukturalny dzieła łączy na zasadzie kontrapunktu różne idee, „różne aspekty świata przedstawionego". I przekonuje, że w każdym dziele Dostojewskiego można odnaleźć „«statyczny» układ pewnych wartości «przekładalnych» na różne formy literackiej konkretyzacji” "53 a więc postaci, wydarzenia, motywy. Dlatego też w twórcy Braci Karamazow widzi prekursora dwudziestowiecznej estetyki dysonansu, obecnej nie tylko w literaturze, ale i w sztuce, czego dowodzić może dodekafoniczna technika w muzyce. Polemika z Bachtinem nie oznacza wszakże zakwestionowania jego koncepcji, lecz pragnienie jej rozszerzenia. Filozofię pisarza traktuje Brzoza jako projekt „hermeneutycznej antropologii”, choć podkreśla, że nie da się istoty tej twórczości zamknąć w jakiejś choćby najbardziej uniwersalnej formule. Badaczka kontynuowała swoje refleksje nad światopoglądem autora Biesów w książce poświęconej specyfice relacji między „regułami metodologicznymi” stosowanymi przez Dostojewskiego a myślą egzystencjalną i hermeneutyką filozoficzną ${ }^{54}$. Inspirujące badania Brzozy wydaje się wszakże charakteryzować zbyt częsta „ucieczka” spod „kontroli naukowo-filozoficznej”, gdy próbuje ona połączyć antropologiczną myśl ojców Kościoła prawosławnego z egzystencjalizmem Martina Heideggera i Alberta Camusa, z hermeneutyką Paula Ricoeura, a także ze sztuką Tadeusza Kantora.

Halina Chałacińska-Wiertelak, której najbliżej chyba do holistycznej koncepcji kultury, stara się połączyć orientację fenomenologiczną z semiotycznąa $a^{55}$ Bada

51 H. Brzoza, Dostojewski - myśl i forma, Łódź 1984; eadem, Аостоевский. Просторы движушегося сознания, Poznań 1992.

52 Ibidem, s. 208.

53 Ibidem, s. 211.

54 Eadem, Dostojewski. Między mitem, tragedia i apokalipsą, Toruń 1995, s. 15.

55 H. Chałacińska-Wiertelak, Idea teatru w powieściach Dostojewskiego, Poznań 1988; eadem, Komparatystyczne orientacje tekstu artystycznego. Próby interpretacji dziet kultury rosyjskiej, Poznań 2007. 
dzieło literackie, sytuując je w sieci kulturowych kontekstów. W ten sposób też odczytuje powieści Dostojewskiego, w których doszukuje się (dosłuchuje) rezonansu innych form artystycznych. Szczególną uwagę zwraca na „teatralność” scen w jego powieściach. Autor Idioty w istotny sposób pomógł badaczce wypracować naukowe modus operandi. W pracy na temat "kodu kulturowego w dziele literackim” zdefiniowała je jako wypracowaną dzięki badaniom interdyscyplinarnym formułę „humanistycznego poznania”, w którym dzieło literackie rozumiane jest jako „żywy i twórczy organizm, kreujący obszerne konteksty duchowe" ${ }^{156}$. Interpretacje tekstów literatury rosyjskiej XIX-XX wieku skłoniły badaczkę do postawienia odważnej tezy o „świecie Dostojewskiego jako kodzie kulturowym XXI wieku”57.

Istotny nurt polskiej dostojewskologii lat siedemdziesiątych stanowiły badania poświęcone recepcji twórczości rosyjskiego pisarza. Można by je uznać za równie „neutralne” ideologicznie jak strukturalistyczne bądź fenomenologiczne próby lektury twórcy Mtokosa. Telesfor Poźniak analizował znaczenie Dostojewskiego dla symbolistów rosyjskich, którzy po latach „czyśćca” wprowadzili go na nowo na salony literackie Rosji ${ }^{8}$. Nie zabrakło także prac poświęconych miejscu Dostojewskiego w twórczości polskich pisarzy. Ludmiła Jazukiewicz-Osełkowska ${ }^{59} \mathrm{w}$ bardzo kompetentnej pracy ujawniła znaczenie rosyjskiego twórcy dla dzieła Stanisława Brzozowskiego, największego młodopolskiego orędownika literatury rosyjskiej, oraz znacznie bardziej skomplikowany stosunek Stefana Żeromskiego do autora Idioty. Zamknięcie polskiej refleksji dostojewskologicznej lat siedemdziesiątych stanowi wielka, ,inwentaryzacyjna” (w dobrym tego słowa znaczeniu) publikacja Franciszka Sielickiego poświęcona recepcji klasyków prozy rosyjskiej w międzywojniu ${ }^{60}$. Szkic o obecności Dostojewskiego w prozie, krytyce i w teatrze dwudziestolecia Sielicki opublikował jeszcze na początku lat siedemdziesiątych, ale na książkę, w której ów artykuł został pomieszczony (obok analogicznej refleksji nad miejscem Lwa Tołstoja, Iwana Turgieniewa, Nikołaja Gogola, Antona Czechowa i Michaiła Sałtykowa-Szczedrina), musiał autor parę lat poczekać. Stanowiła ona uwieńczenie iście benedyktyńskiej pracy, dzięki której badacz polskiej recepcji Dostojewskiego od jej początku aż do końca okresu międzywojennego uzyskał bezcenny kapitał. W książce Sielickiego znajdzie bowiem rzetelny, niemal pełny wykaz prac krytycznych, tekstów artystycznych polskich twórców, w których pobrzmiewa jakieś echo

56 H. Chałacińska-Wiertelak, Культурный код в литературном произведении, s. 38-39.

57 Ibidem, s. 197-199.

58 T. Poźniak, Dostojewski w kręgu symbolistów rosyjskich, Wrocław 1969.

59 L.Jazukiewicz-Osełkowska, Fiodor Dostojewski w twórczości Stanistawa Brzozowskiego i Stefana Żeromskiego: studium porównawcze, Warszawa 1980.

60 F. Sielicki, Klasycy dziewiętnastowiecznej prozy rosyjskiej w Polsce międzywojennej, Warszawa 1985. 
Dostojewskiego, także inscenizacji jego utworów. Ma jednak owa praca charakter klasycznie „wpływologiczny”, brak niestety refleksji, czemu owe wpływy służyły ${ }^{6 \mathrm{r}}$.

Jubileuszowy rok stulecia śmierci Dostojewskiego (198I) dowiódł zwycięskiej obecności pisarza w kulturze polskiej. Ukazał się wówczas specjalny numer „Znaku" poświęcony Fiodorowi Michajłowiczowi, a w nim ankieta Dostojerwski dzisiaj. Wzięli w niej udział wybitni pisarze polscy (Czesław Miłosz, Jerzy Andrzejewski, Tadeusz Różewicz, Władysław Terlecki, Paweł Hertz, Jarosław Marek Rymkiewicz, Janusz Pasierb, Zbigniew Żakiewicz) i badacze literatury (Maria Janion, Ryszard Przybylski). Pytania ankiety dały możliwość ujawnienia stosunku emocjonalnego: od deklaracji zasadniczej obcości (Rymkiewicz), poprzez obojętność (Andrzejewski), po niekwestionowany podziw (Przybylski). Ale stwarzały też okazję do dyskusji na tematy antropologiczne i teologiczne, pozwalały ujawnić aktualność problematyki podjętej przez Dostojewskiego. Dwa lata później specjalny numer poświęciła pisarzowi „Literatura na Świecie” (1983). Uniwersytet Łódzki zorganizował wielką jubileuszową konferencję Fiodor Dostojerwski - myśl i dzieto i wydał książkę ze zbiorem szkiców konferencyjnych ${ }^{62}$. Podobne spotkanie naukowe, które również zaowocowało publikacją, zorganizowała Wyższa Szkoła Pedagogiczna w Rzeszowie $^{63} . Z$ rocznicą tą wiąże się także już w tytule książka Adolfa Rudnickiego Sto lat temu umart Dostojezski (wydana poza zasięgiem cenzury). Widzieć w niej należy ukoronowanie stałej obecności autora Idioty w twórczości Rudnickiego. Konstatacjom nad twórczością Dostojewskiego towarzyszą zapisy gorących dni w Polsce po sierpniowym przełomie. Doskonały pomysł połączenia obu nurtów refleksji na pewno wyrasta z przekonania o aktualności myśli Dostojewskiego, która może służyć pomocą w zrozumieniu skomplikowanej rzeczywistości.

W I98I roku swoją pierwszą książkę, zatytułowaną Dostojerwski: dialektyka niewiary, opublikowała Danuta Kułakowska, sześć lat później pojawiła się jej druga publikacja $^{64}$. To kolejne prace poświęcone światopoglądowi rosyjskiego pisarza, przede wszystkim jego prawosławnej chrystologii i historiozofii. Kułakowska, opierając się na metodologii marksistowskiej (choć bliski jest jej także socjologiczny genetyzm), krytykuje tezę Michaiła Bachtina o braku przyczynowości w powieściach twórcy. Nie kryjąc swojego religijnego indyferentyzmu, powątpiewa w prawdziwość wiary Dostojewskiego, zauważa raczej jej uzależnienie od historiozoficznych idei pisarza. Widzi w nim Kułakowska twórcę, który "genialnie antycypuje ledwie zarysowujące

$61 \mathrm{Z}$ prac wydanych w latach siedemdziesiątych należy jeszcze wspomnieć popularnonaukową broszurę Józefa Smagi Fiodor Dostojewski (1974). Znacznie ważniejsze były wstępy tego uczonego do wydań powieści rosyjskiego twórcy w Bibliotece Narodowej: Zbrodni i kary $(1987,1992)$ oraz Braci Karamazow (1995).

62 Fiodor Dostojewski - myśl i dzieto. W setna rocznice śmierci pisarza, red. O. Główko, Łódź 1981.

63 Fiodor Dostojewski w setna rocznice śmierci.

64 D. Kułakowska, Dostojewski. Antynomie humanizmu wedtug „Braci Karamazowów”, Wrocław 1987, z. 1/4. 
się wówczas antynomie gwałtownie laicyzującej się świadomości”" ${ }^{35}$, który boi się konsekwencji odrzucenia nauk Chrystusa i snuje wizje życia człowieka na własne ryzyko, co Herling nazywał „wyzwoleniem z przesądów”. Autorka zauważa, że bohaterowie pisarza "«mówią o Bogu», ale nie «rozmawiają z Bogiem»" ${ }^{66}$, próbuje więc wskazać jądro myśli Dostojewskiego. Umieszcza w nim alternatywę religii i ateizmu (nie w sensie opozycji, ale dialogu), Chrystusa i Antychrysta albo, lepiej, zasadę „bez Chrystusa” i „z Chrystusem”. Otóż w tej antynomii widzi badaczka dialektyczną istotę chrystologii pisarza, która przyjmuje wymiar „negatywny” bądź „pozytywny”, ale owa kwalifikacja w żadnym razie nie ma charakteru wartościującego. Kułakowska przeciwstawia się więc ujęciom, które z założenia deprecjonują „pozytywne treści ateizmu” ${ }^{67}$. Analizuje powieściowe inkarnacje „chrystologii negatywnej” (Raskolnikow, Stawrogin, Iwan Karamazow), z istotnym zróżnicowaniem postaw ateistycznych, i mniej oryginalne personifikacje „chrystologii pozytywnej” (Sonia, Myszkin, Alosza, Zosima). Przekonuje, że ateizm w ujęciu Dostojewskiego to raczej nie „negacja Boga, lecz zakwestionowanie moralnych i [...] światopoglądowych konsekwencji religijnego kreacjonizmu" ${ }^{68}$. Do kwestii dialektyki wiary i niewiary (potrzeby i niemożności) powróciła Kułakowska w książce poświęconej „antynomiom humanizmu” Dostojewskiego. Skupiła się w niej już „tylko” na Braciach Karamazow, widząc w tym dziele ostatnią próbę dojścia pisarza do syntezy humanizmu, ze swej istoty antropocentrycznego, z wizją chrześcijańską, zatem teocentryczną. Znaczenie książek Kułakowskiej podkreślał Kapuścik, który zwrócił uwagę, że religioznawcze spojrzenie autorki pozwala jej czytelnikowi dostrzec oba elementy światopoglądu powieściopisarza: soteriologiczny i heretycki bądź - mówiąc delikatniej - niekanoniczny ${ }^{69}$.

W wiarę Dostojewskiego nie wątpi natomiast Anna Raźny i jej odzwierciedlenia szuka w dziele pisarza. W książce Fiodor Dostojerwski. Filozofia cztowieka a problemy poetyki odrzuca koncepcje przypisujące poetyce charakter autonomiczny (Michaił Bachtin, Jurij Tynianow, Anatolij Winogradow) i deklaruje, że nadrzędne dla niej są uniwersalia człowieczeństwa, nie zaś uniwersalia formy. Poddaje więc dzieło pisarza interpretacji wartościującej, wspomagając się głównie hermeneutyką Ricoeura, fenomenologią (Edmund Husserl, Max Scheler), egzystencjalizmem (Søren Kierkegaard) i jego chrześcijańską odmianą (Gabriel Marcel). Dla Anny Raźny nie ma wartości poza chrześcijaństwem i nie ma prawdy poza Chrystusem.

65 Eadem, Dostojewski: dialektyka niewiary, Warszawa 1981, s. 27.

66 Ibidem, s. 89.

67 Ibidem.

68 Ibidem, s. 224.

69 J. Kapuścik, op. cit., s. 130. 
Stara się więc przekonać, że filozofia człowieka i filozofia wartości pisarza „mają wybitnie chrześcijański charakter"7o. Identyfikuje ,jedyną chrześcijańską prawdę" Dostojewskiego $\mathrm{z}$,jedyną ludzką prawdą" wyrażoną przez filozofów patronujących jej interpretacjom. Autor Zbrodni i kary to dla badaczki pisarz chrześcijański, nie zauważa więc w jego dziele żadnych konfliktów filozoficznych ani niekonsekwencji światopoglądowych. Raźny sięgnęła też do antropologii filozoficznej księdza Józefa Tischnera, który w Filozofii dramatu (1990), pokazując stosunek człowieka do prawdy i do zbrodni, odwoływał się również do doświadczeń Raskolnikowa. Ale jego stosunek do prawdy był zasadniczo odmienny od postawy badaczki.

Kilkanaście lat po pracy Anny Raźny pojawiła się publikacja Hałyny Kryshtal, ukraińskiej badaczki piszącej także w języku polskim. Autorka podjęła refleksję nad złem, traktowanym jako „jeden z zasadniczych wątków twórczości”포 Dostojewskiego, z perspektywy teologii moralnej. W takim duchu zastanawia się nad złem metafizycznym, fizycznym i moralnym. Rozważa stosunek człowieka do Boga, do siebie i do społeczeństwa. Kryshtal bada źródła, przejawy i konsekwencje oraz formy przezwyciężania zła. W podtytule określiła swoją książkę jako „studium teologicznomoralne". I niemal w kaznodziejskim duchu przekonuje, że przezwyciężyć zło można tylko przez zanurzenie w Chrystusie. Przywołuje bodaj najsłynniejsze zdanie Dostojewskiego, że „kiedy nie ma Boga, wszystko jest dozwolone”. Według autorki bez Boga nie ma też moralności.

Jednocześnie z pracą Raźny, w tym samym roku I988, ukazała się książka Andrzeja de Lazari „Poczwiennictwo”. Z badań nad historia idei w Rosji ${ }^{2}$. Autor proponuje odczytanie spuścizny rosyjskiego pisarza radykalnie odmienne od interpretacji Anny Raźny. Dla badacza główną kategorią, na której zbudowano światopogląd poczwienników, w tym Dostojewskiego, jest romantyczna „narodowość” („народность”). W kategorii owej de Lazari upatruje fundamenty ich historiozofii, estetyki, a nawet religii. Według niego bowiem „narodowość” doprowadziła do tego, że prawosławie stało się u Dostojewskiego kategorią historiozoficzną. De Lazari opublikował rów-

70 A. Raźny, Fiodor Dostojewski. Filozofia cztowieka a problemy poetyki, Kraków 1988, s. 135.

71 H. Kryshtal, Problem zta w twórczości F. Dostojewskiego. Studium teologiczno-moralne, Lublin 2004, s. 15.

72 W języku rosyjskim książka ukazała się pod tytułem B кругу Федора Аостоевского. Почвенничество (Moskwa 2004). Oprócz niej Andrzej de Lazari wydał w języku rosyjskim następujące prace poświęcone Dostojewskiemu: Григорьевские мотивы в „Речи о Пуикине” Ф. Аостоввского, „Revue des Etudes Slaves", Paris 1988, t. 59, fascicule 4; Категория народности у Аостоевского и в эстетике соиреализма, „Русская мысль", Paris 1989, № 3789; Аостоевский как идеологический авторитет в политической борьбе наших дней (о категории „всечеловечности”), „Dostoevsky Studies. New Series” 1998, vol. 2, № 1; Категории народа, народности и всечеловечности в мировоззрении Федора Аостоевского и его духовнысх наследников, w: ХХІ век глазами Достоевского: перспективы человечества, „Грааль”, Москва 2002; Гегельянство в почвенническом восприятии, „Dostoevsky Studies” 2004, vol. 8; Аостоевский как зеркало „консервативной революиии”, „НГ Религии” 2004, № 18; Культурнал запрограммированность Достоевского, его героев и исследователей его творчества, w: Sub specie tolerantiae. Памятии B. А. Туниманова, Санкт-Петербург 2008. 
nież artykuł o rosyjskim geniuszu w czwartym tomie rosyjsko-polsko-angielskiego leksykonu Idee w Rosji (którego był pomysłodawcą i redaktorem). Jego artykułowi towarzyszyły w tym samym tomie szkice polskiego księdza prawosławnego Henryka Paprockiego oraz rosyjskiego uczonego Konstantina Isupowa. Umieszczenie trzech równoległych tekstów wynika z postmodernistycznej formuły leksykonu, która zakłada kilka, nawet sprzecznych, interpretacji konkretnej idei. Formuła owa perfekcyjnie sprawdza się, czego dowodzą szkice, w refleksji nad myślą Dostojewskiego.

$Z$ innych książek wydanych w latach osiemdziesiątych przypomnieć trzeba niezwykle oryginalną w polskiej dostojewskologii publikację Barbary Stempczyńskiej o malarskich zainteresowaniach pisarza. Autorka zainspirowana syntetycznym kierunkiem w literaturoznawstwie radzieckim, postulującym badanie typologicznie tożsamych lub bliskich zjawisk ideowo-estetycznych w sztuce słowa i sztukach plastycznych danej epoki, podjęła próbę zrekonstruowania sympatii malarskich autora Biesów, ujawnionych w Dzienniku pisarza i w jego listach. Z książki Stempczyńskiej czytelnik dowie się nie tylko, że pisarz cenił wysoki poziom artystyczny, ale również, że był zwolennikiem malarstwa wyrażającego prawdy uniwersalne, o wysokich ideałach moralnych, wolnego od tendencyjności społeczno-politycznej.

Od początku lat dziewięćdziesiątych nastąpił niezwykły rozwój polskiej dostojewskologii, ideologia przestała ograniczać badaczy, powstało mnóstwo prac zaskakująco różnych pod względem metodologicznym. Dominującej hermeneutyce towarzyszy zwykle historia idei, prace często mają charakter interdyscyplinarny. W 1992 roku ukazała się książka Telesfora Poźniaka Dostojerwski i Wschód. Jeszcze przed tą publikacją autor był niekwestionowanym autorytetem w polskiej rusycystyce i znawcą twórczości rosyjskiego pisarza. W kolejnej pracy zajął się wątkami światopoglądowymi Dostojewskiego (któremu towarzyszą Nikołaj Danilewski oraz Konstantin Leontjew) dotyczącymi Wschodu. Przeanalizował miejsce mitu azjatycko-koranicznego, bizantyńskiego, biblijnego, wreszcie znaczenie problemów żydowskich w myśli rosyjskiego pisarza. Zwrócił też uwagę na istotne znaczenie w jej ewolucji aktualnych wówczas kwestii politycznych („Konstantynopol musi być nasz!"). Rosyjski twórca to dla badacza niewątpliwie wielki pisarz, spóźniony myśliciel romantyczny, to „osobowość pisarska ukształtowana na pograniczu kultury słowiańsko-ortodoksyjnej i orientalnej”73, ale także „duchowy ojciec rosyjskiego mesjanizmu, ksenofobicznego nacjonalizmu, zwłaszcza antysemityzmu"74.

Problematykę religijnej historiozofii i mesjanizmu autora Biesów badał też Michał Bohun, który przekonująco ukazał, na ile obcy Dostojewskiemu był świat zachodnich wartości (racjonalizm, katolicyzm). Unaocznił źródła nadziei pisarza

73 T. Poźniak, Dostojewski i Wschód: szkice z pogranicza kultur, Wrocław 1992, s. 140.

74 Ibidem, s. 100. 
w zbawczy charakter prawosławia, tradycyjnej kultury rosyjskiej z jej „zaświatowym ideałem”, która otworzy „drogę ludzkości do Królestwa Bożego”75. Problem zła, pytanie unde malum, wreszcie ,inwersja pojęć etycznych" stanowią kluczowe tematy dzieł wybitnego filozofa i historyka filozofii, a jednocześnie znakomitego eseisty Cezarego Wodzińskiego. Najpierw wydał on książkę Św. Idiota. Projekt antropologii apofatycznej ${ }^{76}$ poświęconą zjawisku i fenomenowi jurodstwa, często odwołując się do Dostojewskiego, by refleksję nad pisarzem zamknąć w eseju Trans, Dostojewski, Rosja, czyli o filozofowaniu siekiera. W błyskotliwej formie zadaje w nim autor odważne pytania, zapewne kompromitujące „zwykłego” badacza. Odwołuje się do rosyjskiej myśli, w której podkreśla bardzo poważny stosunek do metafizyki, zagubiony już na Zachodzie. Nie ukrywa swojej niechęci wobec „słowiańskiej histerii” Dostojewskiego, ale przecież, może trochę bezradnie, konstatuje, że bez niego „ani rusz"77. Inaczej niż Miłosz, który czytał Dostojewskiego w kontekście zachodniej myśli przyswojonej nazbyt poważnie przez Rosjan, Wodziński nie wykracza poza Rosję. Podwaliny myśli pisarza widzi w Raskole, który zainfekował rosyjskie uniwersum chaosem. Od tego momentu rosyjska duchowość nabrała charakteru chłystowskiego transu. Raskoł, jak dowodzi Wodziński, doprowadził do „gruntownej zatraty zdolności rozróżniania, że siekiera służy raczej do rąbania drewna aniżeli do rąbania staruszek ${ }^{38}$. Dlatego proponuje rewelacyjne odczytanie dzieła Fiodora Michajłowicza... Raskolnikowa w kontekście świata na opak, będącego konsekwencją stale obecnego w duchowości rosyjskiej Raskołu, który prowadzi do utraty zdolności rozróżniania dobra od zła. Wodziński uważa, że Dostojewski stara się przywrócić tę utraconą zdolność, szuka „zaświata” dla świata Raskołu.Jest doskonałym wyrazicielem duchowego chaosu, ale także pragnienia znalezienia wyjścia z impasu. I „dobija się łaski za pomocą siekiery”. „Kto poza Dostojewskim odważył się na taką próbę?”79 - pyta Wodziński. Kto poza Wodzińskim odważyłby się na takie odczytanie?

$\mathrm{Na}$ Bohunie i Wodzińskim nie zamyka się lista polskich filozofów, którzy podejmują badania nad Dostojewskim. Poczesne miejsce wypracowali sobie Jacek Uglik czy Marian Broda. Pierwszy z nich w refleksjach nad „dramatem człowieka"80 zwraca uwagę na przekonania pisarza o niebezpieczeństwie wynaturzeń osobowości ludzkiej, o zagrożeniu dla ładu społecznego, jakie niosły

75 M. Bohun, Fiodor Dostojewski i idea upadku cywilizacji europejskiej, Katowice 1996, s. 130.

76 C. Wodziński, Św. Idiota. Projekt antropologii apofatycznej, Gdańsk 2000.

77 Idem, Trans, Dostojewski, Rosja, czyli o filozofowaniu siekierą, Gdańsk 2005, s. 5.

78 Ibidem, s. 6, 59.

79 Ibidem, s. 121.

80 J. Uglik, Dostojewski, czyli rzecz o dramacie cztowieka, Warszawa 2014. 
zachodnie idee filozoficzne (racjonalizm, materializm, ateizm). Patrzy wszakże autor $\mathrm{z}$ aktualnej perspektywy aksjologicznej, niepozwalającej postawić znaku równości między ateizmem a złem. Nie widzi więc w pisarzu myśliciela dialogu, a w jego twórczości polifonii, ponieważ nie jest on w stanie przekroczyć granic prawosławia i wyjşć ku Innemu. Dlatego też akcentuje w tytule dramat człowieka jako efekt narzucenia przez Dostojewskiego, pragnącego ośmieszyć „zgubne” idee, jednowymiarowości: za Bogiem bądź przeciw Niemu, co dla autora broniącego filozofii zachodniej, zachodniego chrześcijaństwa oznacza pomniejszenie i poniżenie, oznacza status istnienia dramatycznego. Broda $\mathrm{z}$ kolei w dziełach twórcy Biesów (obok Sołowjowa i Leontjewa) widzi jeden z ważniejszych kluczy do zrozumienia mistycznej Rosji. W dynamice myśli Dostojewskiego, w trójfazowej koncepcji czasu przebiegającego od pierwotnej jedności, poprzez stan wyobcowania, po wypracowaną dojrzałą jedność autor próbuje odnaleźć jedną z możliwych historiozoficznych odpowiedzi na „przeznaczenie” Rosji, poddanej podobnemu rytmowi rozwoju. W finalnym etapie, jak sądził autor Dziennika pisarza, Rosja nie tylko odzyska jedność wewnętrzną, ale doprowadzi do „ogólnego zjednoczenia świata i powszechnej miłości ludzi”»r.

W ekumenicznym duchu do twórczości Dostojewskiego podeszła Anna Kościołek. Jej zainteresowania koncentrują się wokół Dziennika pisarza, badaczka nie podejmuje jednak problemów historiozoficznych bądź kwestii kontrowersyjnych, których nie brak przecież w Dzienniku..., i skupia się przede wszystkim na wartościach chrześcijańskiego świata twórcy Zbrodni i kary ${ }^{82}$. W kolejnej swojej książce Kościołek, jakby „zmotywowana” opinią Kułakowskiej o braku zainteresowania badaczy Dziennikiem pisarza $a^{83}$, podjęła próbę jego monograficznego ujęcia. Trzeba tu przypomnieć, że wcześniejsze szkice poświęcone temu dziełu opublikował Ryszard Łużny ${ }^{84}$, który miał również istotny wkład w jego polską edycję. W swojej monografii Kościołek zajęła się genezą utworu i celami, jakie autor stawiał przed Dziennikiem pisarza. Usystematyzowała poruszane w nim problemy(piękno jako kategoria estetyczno-etyczna, rosyjska codzienność, lud-naród rosyjski i „święta Ruś”), dokonując pewnego zróżnicowania poglądów pisarza-publicysty i pisarza-artysty. Ważny rozdział pracy stanowi lektura tekstów artystycznych Dostojewskiego zamieszczonych w Dzienniku... (Bobok, Eagodna, Sen śmiesznego cztowieka).

81 M. Broda, „Zrozumieć Rosje”? O rosyjskiej zagadce-tajemnicy, Łódź 2011, s. 154.

82 A. Kościołek, Cztowiek Ewangelii w „Dzienniku pisarza” Fiodora Dostojewskiego, Toruń 1994; eadem, „Dziennik pisarza” Fiodora Dostojewskiego. Próba monografii, Toruń 2000.

83 D. Kułakowska, Dostojewski: dialektyka niewiary, s. 77.

84 R. Eużny, Między publicystyka a beletrystyka, czyli „Dziennik pisarza” Fiodora Dostojewskiego, w: Fiodor Dostojewski - myśl i dzieto..., s. 3-14; idem, Nad Fiodora Dostojewskiego „Dziennikiem pisarza”. Sprawozdania z posiedzeń Komisji naukowych PAN w Krakowie, t. XXIII/1, Wrocław 1981, s. 34-35. 
Wierny duchowi ekumenizmu jest także Grzegorz Przebinda. Czyta on twórcę Biesów w kontekście myśli Sołowjowa, ale również Karola Wojtyły, który jest dla niego najwyższym autorytetem. Przebinda nie opublikował książki o Dostojewskim, jednak z jego licznych szkiców literackich i religijnych o twórcy Idioty ${ }^{85}$ taką książkę z pewnością można wydać. W sposób wolny od jakichkolwiek akcentów konfesyjno-homilijnych spojrzała natomiast na dzieło twórcy Biesów Dorota Jewdokimow, która uważa się za uczennicę Igora Jewłampijewa, zwolennika monistycznego modelu interpretowania dzieła Dostojewskiego ${ }^{86}$. W takim duchu Jewdokimow analizuje też rosyjskiego geniusza. W pierwszej części swojej monografii ${ }^{87}$ autorka podejmuje refleksje nad związkami między sztuką i religią, w estetyce odnajdując wyraz przekonań metafizycznych, w drugiej zaś zastanawia się nad specyfiką relacji Boga i człowieka w powieściach, dziennikarstwie i listach autora Idioty.

O religijnej „tajemnicy człowieka” pisze wspomniany już kapłan, filozof i tłumacz Henryk Paprocki w książce Lew i mysz, której tytuł nawiązuje do „ulubionego" bohatera rosyjskiego twórcy. Badacz dostrzega istotne podobieństwa w konstrukcji postaci powieściowych. Ich podstawą jest dialektyka mocy (lew to podświadomość) i słabości (mysz to sumienie). Ale w odczytaniu autora siła jest słabością, a słabość jest siłą. Według Paprockiego Dostojewski-artysta buduje nową antropologię, której podstawowym elementem jawi się istota ludzka, określona przez autora jako „człowiek z podziemia”, i walczy o ludzką duszę w nowożytnej epoce „pozbawionej uprzedzeń” ${ }^{88}$. Parę lat po książce Paprockiego pojawiła się publikacja prawosławnego biskupa Szymona Romańczuka Pisarz i Bóg, w której pomieszczone zostały artykuły powstałe kilkadziesiąt lat wcześniej. Szkice skomponowane w dużej mierze z cytatów z pism Dostojewskiego (i jego badaczy, łączących pisarza z Zosimą) genologicznie przypominają bardziej homilię niż tekst naukowy. Zasadniczo jednak wpisują się w dychotomiczne rozumienie postawy wobec Boga: albo „opętani”, czyli buntownicy, albo „piękni”, czyli ci, „którzy szli za Chrystusem” ${ }^{89}$. Nieco inne podejście do dziedzictwa Dostojewskiego prezentuje katolicki ksiądz Dariusz Jastrząb. Na duchowy świat pisarza patrzy przez pryzmat kulturowy i teologiczny, ale w autorze Idioty widzi

85 G. Przebinda, Sotowjow wobec Dostojewskiego, w: idem, Sotowjow wobec historii, Kraków 1992; idem, Historia a dzień wspótczesny w naszej Europie. Wojtyta czyta Dostojewskiego i Sotżenicyna, „Ethos” 2002, nr 3-4; idem, Dostojewski o nieśmiertelności duszy i raju pozaziemskim, w: idem, Między Moskwa a Rzymem. Myśl religijna w Rosji XIX i XX wieku, Kraków 2003.

86 Zob. T. Obolevitch, Dostojewski jako metafizyk. Próba metarefleksji, w: Metafizyka a literatura w kulturze rosyjskiej. Метафизика и литература в русской культуре, red. eadem, Kraków 2012, s. 174.

87 D. Jewdokimow, Cztowiek przemieniony. Fiodor M. Dostojewski wobec tradycji Kościota Wschodniego, Poznań 2009.

88 H. Paprocki, Lew i mysz, czyli Tajemnica cztowieka: esej o bohaterach Dostojewskiego, Białystok 1997.

89 S. Romańczuk, Pisarz i Bóg: Dostojewski, Gogol, Totstoj, Białystok 2013, s. 37. 
„najpierw artystę, a dopiero potem filozofa czy teologa" ${ }^{\circ}$. Dlatego też rozumie, ale i docenia wszelkie antytezy i niespójności w dziele rosyjskiego geniusza. Mimo tych „sprzeczności” Dostojewski urasta w oczach Jastrzębia do roli chrześcijańskiego przewodnika. Nie ujmuje go autor jako myśliciela antykatolickiego, stara się natomiast dowieść, że Chrystus, którego pisarz bronił przed zredukowaniem do poziomu abstrakcyjnej idei, stanowił dla niego rzeczywiste centrum Wszechświata i dawał nadzieję na złagodzenie aksjologicznego chaosu. Szczególną rolę w tym dziele przypisywał Jastrząb Idiocie.

Kilka lat wcześniej znakomitą monografię tej powieści opublikowała Elżbieta

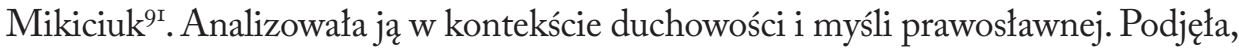
wbrew powszechnym prawie opiniom, odważną próbę „rehabilitacji” tytułowej postaci utworu. Autorka odrzuca dominującą tezę o niemocy „pięknego człowieka” w świecie zła i błyskotliwie udowadnia, że perspektywa ewangeliczna, typowa dla ,ikonopisania”, zawiera się już w kompozycji powieści. Doświadczenie wejścia w mroczną stronę ludzkiej egzystencji oznacza przede wszystkim pragnienie znalezienia czystego piękna. Myszkin musi iść do grobu nie tylko po to, aby zostać wskrzeszonym, ale po to, aby ocalić świat wokół siebie (do tej idei nawiąże także Jastrząb). Natomiast w pracy na temat „teatru paschalnego" pisarza ${ }^{92}$ Mikiciuk przekonuje, że Dostojewski ujawnia ewangeliczne prawdy w „dramaturgicznym działaniu”. Sięgając po filozofię dialogu, badaczka argumentuje, że wymiar ewangeliczny w pełni ujawnia się w czasie spotkań człowieka z człowiekiem. Fundamentalnym sensem „teatru paschalnego” jest więc „przejście” (pascha) postaci powieściowych Dostojewskiego od śmierci do życia.

Książka Mikiciuk zamknęła pierwsze dziesięciolecie polskiej dostojewskologii XXI wieku. Nie zamknęła jednak poszukiwań. Ostatnia dekada, która dowodzi niesłabnącej popularności wiecznie aktualnych „przeklętych problemów” Dostojewskiego, zaowocowała kilkoma ważnymi publikacjami. Otworzyła ją książka niezwykła: Nowy Testament Fiodora Dostojewskiego w opracowaniu Adama Bezwińskiego. Autor zebrał w niej fragmenty zaczerpnięte z pozostawionego przez pisarza egzemplarza Nowego Testamentu, które zostały przez niego w jakiś sposób oznaczone. We wstępie do tej swoistej antologii dokonał edytor krótkiego przeglądu polskich badań, szczególnie tych poświęconych „wewnętrznemu światu pisarza”, skupionych na inspiracyjnym znaczeniu Dobrej Nowiny ${ }^{93}$. Do grona zasłużonych

90 D. Jastrząb, Duchowy świat Dostojewskiego, Kraków 2009, s. 20.

91 E. Mikiciuk, „Chrystus w grobie” i rzeczywistośc „Anastasis”. Refleksje na temat „Idioty” Dostojewskiego, Gdańsk 2003.

92 Eadem, Teatr paschalny Fiodora Dostojewskiego. O watkach misteryjnych „Braci Karamazow” $i$ ich wizjach scenicznych, Gdańsk 2009.

93 A. Bezwiński, Fiodor Dostojewski i jego Nowy Testament, w: Nowy Testament Fiodora Dostojewskiego , przygotował i wstępem opatrzył A. Bezwiński, Bydgoszcz 2011, s. 16. 
badaczy twórczości dołączyło najmłodsze pokolenie, odważnie deklarujące chęć odczytania Dostojewskiego „na nowo" 94 . Pisze tak Marcin Borowski, podobnie przekonuje Michał Kruszelnicki. Ten „rewizjonizm” dowodzi, że twórczość Dostojewskiego jest ciągle żywa, że wiele w niej jeszcze można odnaleźć. Młodzi autorzy nie odrzucają wyników dotychczasowych odczytań, lecz w dialogu z nimi przedstawiają własne przemyślenia. Najlepszym dowodem pokoleniowej symbiozy zdaje się książka pod redakcją Anny Raźny Fiodor Dostojewsski i problemy kultury, w której swoje teksty pomieścili zarówno badacze o znaczącym dorobku w zakresie dostojewskologii, jak i adepci tej „nauki”. Łączy ich uznanie istotnego miejsca świata wartości w refleksji twórcy Idioty. Analizując aksjologię pisarza w kontekście współczesnej kultury, ,antymetafizycznej i antyaksjologicznej”95, udzielają wszakże różnych odpowiedzi - część z nich religię „sytuuje ponad wolnością”, dla innych wolność okazuje się ważniejsza od religiii ${ }^{6}$.

W kręgu „stosunku do wartości” umieścić także należy publikację Mirosławy Michalskiej-Suchanek ${ }^{97}$ poświęconą problemowi samobójstwa, który w czasach pisarza osiągnął niemal status epidemii. Fenomen ten zmusił autorkę do nakreślenia szerokiego tha historycznego i społecznego. I na tym tle analizuje ona postaci samobójców wykreowane przez twórcę Łagodnej. Dla badaczki Dostojewski to pierwszy myśliciel rosyjski, który śmierć samobójczą traktował jako problem etyczny, aczkolwiek odnosił się do niej ambiwalentnie. W publicystyce winą za „epidemię” obciążał szerzący się w Rosji indyferentyzm etyczny, w powieściach jednak łagodził tę kategoryczną tezę, przyczyn samobójstw poszukując w przestrzeni metafizycznej. W ostatnim czasie pojawiła się kolejna publikacja Michalskiej-Suchanek Piętnaście odston Dostojerwskieg $0^{98}$, w której autorka, przekonana o nierozłączności twórczości z biografią, zdaje się wracać do koncepcji „ludzi żywych”. Może nawet próbuje odbrązawiać geniusza. I w każdej z ról Dostojewskiego: człowieka, pisarza, publicysty poszukuje determinantów jego dzieła.

Na zakończenie tego przeglądu kilka uwag o dokonaniach najmłodszych badaczy. Borowskiego zaintrygował problem ateizmu w twórczości Dostojewskiego. Autor analizuje w książce zarówno sposób kreowania postaci wielkich „ateistów”, jak $\mathrm{i}$,wiarę" ich twórcy. Zastanawia się nad jej specyfiką z perspektywy współczesnych koncepcji ateistycznych, uwypuklając fundamentalne różnice między „ateizmem”

94 M.M. Borowski, Obraz „ateisty” w twórczości Fiodora Dostojewskiego w świetle ateizmu wspótczesnego, Kraków 2015, s. 10.

95 A. Raźny, Stowo wstępne. Fiodor Dostojewski w kregu problemów kultury, w: Fiodor Dostojewski i problemy kultury, red. A. Raźny, Kraków 2011, s. 7.

96 Ibidem, s. 8.

97 M. Michalska-Suchanek, Samobójcy Fiodora Dostojewskiego, Katowice 2015.

98 Eadem, Piętnaście odston Dostojewskiego, Katowice 2018. 
czasów twórcy i ateizmem przełomu wieków XX i XXI. Swoje rozważania traktuje jako formę dialogu między epokami bardzo odmiennymi duchowo. $Z$ tej perspektywy, w ujęciu Borowskiego, Dostojewski, który doświadczał „piekła zwątpienia”, wierzył raczej w wiarę niż w Boga i pragnął być obdarowany łaską wiary „prawdziwej”. Niezbędność wiary łączyła się z przekonaniem o niej jako fundamencie moralności. Z kolei Kruszelnicki na „przeklęte problemy” Dostojewskiego spojrzał z perspektywy egzystencjalnego nurtu myśli europejskiej. Autor tak sformułował temat pracy, że w przestrzeni badań, wydawałoby się dość wyeksploatowanej, znalazł jednak obszar dający możliwość nowatorskiej refleksji nad twórczością Dostojewskiego. W tytułowym „konflikcie i niespełnieniu”99 odnalazł nie tylko fundamentalną zasadę jego twórczości, ale i główny imperatyw zachowań postaci powieściowych, poszukujących za wszelką cenę prawdziwego życia. Dlatego też w obrazie namiętności bohaterów powieściowych dostrzega uzewnętrznienie problemów pisarza. Niezwykle ważnym osiągnięciem badacza jest przyswojenie polskiej dostojewskologii osiągnięć jej anglojęzycznej „partnerki”, większość bowiem prac przywołanych przez Kruszelnickiego nie była tłumaczona na język polski.

4 .

Janina Kulczycka-Saloni w zakończeniu przywołanego na początku szkicu postulowała konieczność wpisania polskiej dostojewskologii w ogólnoświatowe poznanie pisarza ${ }^{\mathrm{IOO}}$, nie przypuszczając chyba nawet, jak rozwinie się ona w kolejnym półwieczu. Przygotowana już parę lat temu bibliografia polskich prac poświęconych Dostojewskiemu $^{\text {IoI }}$, z całą pewnością daleka od kompletności, zawiera kilkadziesiąt pozycji książkowych oraz kilkaset szkiców, artykułów publikowanych w czasopismach naukowych i w pracach zbiorowych. Dlatego trudno byłoby wskazać takie obszary, które miałyby charakter „niezaoranego ugoru”. Znajdziemy tu bardzo szeroki diapazon problemów poetyki, antropologii, historiozofii, religioznawstwa, etyki czy wreszcie estetycznego bądź światopoglądowego wpływu Dostojewskiego na polską i światową literaturę. Są dzieła cieszące się większym zainteresowaniem badaczy, są i takie, które Polaków przyciągają znacznie słabiej, co wcale nie znaczy, że można by było mówić o jakimś polskim kanonie czytania Dostojewskiego. Maria Janion zadeklarowała niegdyś, że najważniejszym dla niej dziełem pisarza jest Sobowwtór.

99 M. Kruszelnicki, Dostojewski: konflikt i niespetnienie, Warszawa 2017.

100 J. Kulczycka-Saloni, Dostojewski w Polsce, s. 48.

101 A. de Lazari, XX, Bibliografia polskich prac o Dostojewskim po 1970 r., w: Аостоевскиŭ. Mamepuaльь и исследования, т. 20, с. 582-597. 
Warto się jeszcze zastanowić, czy polska dostojewskologia wniosła nowe słowo do badań światowych. Bardzo trudno jest udzielić jednoznacznej odpowiedzi, mając świadomość choćby zasadniczo odmiennych odczytań Zbrodni i kary, które zaprezentowali Gombrowicz i Grudziński, czy też diametralnie różnych spojrzeń na Stawrogina. Spróbujmy jednakże zakreślić potencjalny charakter polskiego wkładu w badania twórczości autora Zbrodni i kary. W polskich tekstach poświęconych Dostojewskiemu z całą pewnością pobrzmiewa echo polskiego rozumienia Rosji. Miłosz w Rodzinnej Europie przekonywał, że „Polacy wiedzą o Rosjanach to, co Rosjanie wiedzą o sobie samych, nie chcąc się do tego przyznać, i odwrotnie" „Wiedza” taka oznacza jednak zazwyczaj brak emocjonalnego zdystansowania. O naszych ocenach zbyt często decydują resentymenty, kompleksy, frustracje. Możliwe więc, że emocje te, skrywane w podświadomości, ujawniają się także w trakcie badań nad Dostojewskim. Aczkolwiek polscy uczeni zwykle traktują to zagadnienie ze zrozumieniem, wielkodusznie wybaczając pisarzowi jego nacjonalistyczne skłonności w imię artystycznego geniuszu. Wyciszają naruszone uczucia patriotyczne, ograniczając w pewien sposób zdolność do ujawnienia „polskiego spojrzenia”. Ale trzeba podkreślić jeszcze jedną przeszkodę bądź trudność, otóż polska myśl jest w zasadzie areligijna, skupia się raczej na historii, dlatego też badacze piszący o Dostojewskim muszą dokonać swego rodzaju transgresji.

Inaczej rzeczy miały się z Miłoszem, profesorem literatury słowiańskiej na Uniwersytecie Kalifornijskim w Berkeley, Herlingiem-Grudzińskim, polskim pisarzem, ale żyjącym we Włoszech, i Walickim, historykiem idei, który przez wiele lat wykładał na Uniwersytecie Notre Dame w Stanach Zjednoczonych. Ich „polski głos" (choć z pewnością nie byliby usatysfakcjonowani taką definicją) niewątpliwie wpłynął na zachodnią percepcję rosyjskiej myśli i dziedzictwa Dostojewskiego. Miłosz, Herling-Grudziński i Walicki przeciwstawili się zachodniemu czytaniu dzieł autora Idioty, które z jednej strony, pod silnym wpływem Bachtina, abstrahowało zupełnie od historii, także od poglądów politycznych rosyjskiego geniusza, z drugiej zaś poddane było w niezwykle silnym stopniu psychoanalizie. Historyczne doświadczenie polskich badaczy pozwoliło pokazać Zachodowi Dostojewskiego poczwiennika, tworzącego swoje dzieła właśnie na rosyjskiej „glebie” (poczwie). Dzięki temu dali swoim zachodnim kolegom możliwość lepszego zrozumienia rosyjskiej rzeczywistości, zachodzących w niej procesów i żywych idei. Jednocześnie wpisali rosyjską myśl w ewolucję myśli zachodniej, pokazali jej ogólnoludzkość. W ich stosunku do Dostojewskiego wspólistnieją, ale i walczą dwie przeciwstawne siły: mentalnej obcości determinowanej historią towarzyszy podziw dla rosyjskiej myśli filozoficznej i religijnej, której brakowało polskiej literaturze. I chyba właśnie w ta- 
kim symbiotycznym połączeniu perspektywy uniwersalnej z polskim spojrzeniem zawiera się istota i znaczenie polskich studiów nad twórczością rosyjskiego pisarza.

Tą drogą poszło wielu polskich dostojewskologów, którzy kontynuują badania swych nauczycieli, pozostając w otwartym z nimi dialogu. Najpełniej potwierdza tę tezę książka Dostojerwski i inni: literatura, idee, polityka. Publikacja ta była nie tylko polskim „trybutem” na stopięćdziesiątą rocznicę powstania Zbrodni i kary, ale przede wszystkim hołdem i darem złożonym Profesorowi Andrzejowi de Lazariemu (który wprowadził polską dostojewskologię na światowe audytoria) na jubileusz jego siedemdziesięciolecia. W książce tej znalazły się szkice wielu autorów przywołanych w prezentowanym szkicu. Podejmując „wysiłek znalezienia własnych odpowiedzi na «idee rosyjskie» Profesora" ${ }^{\text {"03 }}$, dowiedli również ciągłej aktualności i ważności dzieła Dostojewskiego.

\section{BibLIOGRAFIA:}

Bezwiński A., Fiodor Dostojewski i jego Nowy Testament, w: Nowy Testament Fiodora Dostojewskiego, przygot. i wstępem opatrzył A. Bezwiński, Bydgoszcz 2011;

Bohun M., Fiodor Dostojewski i idea upadku cywilizacji europejskiej, Katowice 1996;

Borowski M. M., Obraz „ateisty” w twórczości Fiodora Dostojewskiego w świetle ateizmu wspótczesnego, Kraków 2015;

Broda M., „Zrozumieć Rosję? O rosyjskiej zagadce-tajemnicy, Łódź 2011;

Brzoza H., Dostojewski - myśl i forma, Łódź 1984;

Dostojewskij. Prostory dwiżuszczegosia soznanija, Poznań 1992;

Dostojewski. Między mitem, tragedią i apokalipsą, Toruń 1995;

Chałacińska-Wiertelak H., Idea teatru w powieściach Dostojewskiego, Poznań 1988;

Kulturnyj kod w litieraturnom proizwiedienii, Poznań 2003;

Dostojewski i inni: literatura, idee, polityka, red. T. Sucharski przy współudziale M. Michalskiej-Suchanek, Katowice 2016;

Fiodor Dostojewski - myśl i dzieto. W setna rocznicę śmierci pisarza, red. O. Główko, Łódź 1981;

Fiodor Dostojewski w setną rocznicéśmierci, red. M. Bobran, Rzeszów 1985;

Fiodor Dostojewski i problemy kultury, red. A. Raźny, Kraków 2011;

Gombrowicz W., Dziennik 1957-1961, Kraków 1988;

Herling-Grudziński G., Inny świat. Zapiski sowieckie, Londyn 1953;

Dwugtos o sumieniu Raskolnikowa, w: idem, Godzina cieni. Eseje, wybór i oprac. Z. Kudelski, Kraków 1991;

Janion M., Przybylski R., Sprawa Stawrogina, posł. T. Komendant, Warszawa 1996;

Jazukiewicz-Osełkowska L., Fiodor Dostojewski w twórczości Stanistawa Brzozowskiego i Stefana Żeromskiego: studium porównawcze, Warszawa 1980;

Jastrząb D., Duchowy świat Dostojewskiego, Kraków 2009;

103 T. Sucharski, Andrzej de Lazari i idee rosyjskie, w: Dostojewski i inni: literatura, idee, polityka..., s. 11. 
Jewdokimow D., Cztowiek przemieniony. Fiodor M. Dostojewski wobec tradycji Kościota Wschodniego, Poznań 2009.

Kapuścik J., Próba syntezy. Fiodor Dostojewski na warsztacie polskich badaczy w ostatnim trzydziestoleciu, „Przegląd Humanistyczny" 1994, nr 4 (325);

Kościołek A., Cztowiek Ewangelii w „Dzienniku pisarza” Fiodora Dostojewskiego, Toruń 1994;

„Dziennik pisarza” Fiodora Dostojewskiego. Próba monografii, Toruń 2000;

Kruszelnicki M., Dostojewski: konflikt i niespetnienie, Warszawa 2017;

Kryshtal H., Problem zta w twórczości F. Dostojewskiego. Studium teologiczno-moralne, Lublin 2004;

Kulczycka-Saloni J., Dostojewski w Polsce, „Miesięcznik Literacki” 1972, nr 3;

Kułakowska D., Dostojewski. Antynomie humanizmu wedtug „Braci Karamazowów”, Wrocław 1987;

Dostojewski: dialektyka niewiary, Warszawa 1981;

Lazari de A., „Poczwiennictwo”. Z badań nad historią idei w Rosji, Łódź 1988;

Lazari de A., Sucharski T., Bibliografia polskich prac o Dostojewskim po 1970 r., w: Dostojewskij. Matieriaty i issliedowanija, t. 20, Sankt-Petersburg 2014, s. 582-597;

Mackiewicz S., Dostojewski, Warszawa 1957;

Michalska-Suchanek M., Piętnaście odston Dostojewskiego, Katowice 2018;

Samobójcy Fiodora Dostojewskiego, Katowice 2015;

Mikiciuk E., „Chrystus w grobie” i rzeczywistośc „Anastasis”. Refleksje na temat „Idioty” Dostojewskiego, Gdańsk 2003;

Teatr paschalny Fiodora Dostojewskiego. O watkach misteryjnych „Braci Karamazow” i ich wizjach scenicznych, Gdańsk 2009;

Miłosz Cz., Rosja. Widzenia transoceaniczne, t. 1, Dostojewski-nasz wspótczesny, wybór B. Toruńczyk i M. Wójciak, oprac. B. Toruńczyk, wstęp C. Cavangh, Warszawa 2010;

Paprocki H. , Lew i mysz, czyli Tajemnica cztowieka: esej o bohaterach Dostojewskiego, Białystok 1997;

Poźniak T., Dostojewski w kręgu symbolistów rosyjskich, Wrocław 1969;

Dostojewski i Wschód: szkice z pogranicza kultur, Wrocław 1992;

Przebinda G., Między Moskwą a Rzymem. Myśl religijna w Rosji XIX i XX wieku, Kraków 2003;

Przybylski R., Dostojewski i przeklęte problemy. Od „Biednych ludzi” do „Zbrodni i kary”, Warszawa 1964;

Raźny A., Fiodor Dostojewski. Filozofia cztowieka a problemy poetyki, Kraków 1988;

Romańczuk S., Pisarz i Bóg: Dostojewski, Gogol, Totstoj, Białystok 2013;

Rudnicki A., Sto lat temu umart Dostojewski, Warszawa 1984;

Sielicki F., Klasycy dziewiętnastowiecznej prozy rosyjskiej w Polsce międzywojennej, Warszawa 1985;

Sucharski T., Dostojewski Herlinga-Grudzińskiego, Lublin 2002;

Świderska M., Studien zur literaturwissenschaftlichen Imagologie. Das literarische Werk F.M. Dostoevskijs aus imagologischer Sicht mit besonderer Berücksichtigung der Darstellung Polens, München 2001;

Uglik J., Dostojewski, czyli rzecz o dramacie cztowieka, Warszawa 2014;

Urbankowski B., Dostojewski - dramat humanizmów, Warszawa 1978;

Walicki A., Osobowość a historia: studia z dziejów literatury i myśli rosyjskiej, Warszawa 1959.

W kregu konserwatywnej utopii. Struktura i przemiany rosyjskiego stowianofilstwa, Warszawa 1964.

Wedemann M., Polonofil czy polakożerca? Fiodor Dostojewski w piśmiennictwie polskim lat 1847-1897, Poznań 2010;

Wodziński C., Trans, Dostojewski, Rosja, czyli o filozofowaniu siekiera, Gdańsk 2005. 
SŁowA KLUCze: polska dostojewskologia, światopogląd pisarza - światopogląd dzieła, „przestrzeń rezonansowa”, chrystologia, historiozofia

\section{ТААЕУШ СУХАРСКИЙ \\ АОСТОЕВСКИЙ В ПОАЬСКОЙ ПОСАЕВОЕННОЙ ГУМАНИТАРНОЙ МЫСАИ}

Статья представцяет собой попытку подытожить опыт и достижения послевоенной польской рефлексии над творчеством Федора Аостоевского. Русский гений был, наверное, единственным художником, который равно вдохновцял как польских ученых, так и польских писателей. В статье Аоказывается, что интерес вызывали как жизнь автора Братьев Карамазовьх, так и его творчество, часто, впрочем, тоже в контексте биографии. Польское АостоевеАение развивалось в Авух течениях: эмигрантском, свободном от Аавления цензуры, и внутри страны, Ао 1989 г. имевшем существенные цензурные ограничения. Несмотря на это, в 1956-1989 гг. было написано много работ, внесших существенный вкцаА не только в польскую, но и в мировую русистику. На начало 90-х годов пришелся бум польского достоеведения, идеология перестала ограничивать исследователей, было создано множество методологически УАивительно разнообразных трудов.

В статье рассматривается подавцяющее большинство польских книг, посвященных творчеству, философии и историософии автора Бесов, упомянуты также важнейшие статьи. Показана динамика рефлексии наА Аостоевским, ее проблемное разнообразие (исследования по поэтике романа, берущие начало в концепции Бахтина, вопросы антропологии, религии, историософии, этики, эстетического и мировоззренческого влияния Аостоевского на польскую и мировую митературу) и методологические направления: от биографического подхода, марксизма, структурализма, семиотики, герменевтики до истории идей. Часто работы носили межАисциплинарный характер. Настоящий обзор позволик прийти к выводу, что значение польских исследований Аостоевского состоит в соединении специфически «польского» взгяяда с универсальной перспективой.

КАючевЫЕ САОвА: Польское достоеведение, «пространство резонанса», мировоззрение писателя - мировоззрение произвеАения, христология, историософия 


\section{Tadeusz Suchars Ki}

\section{Dostoevsky in Polish post-WAR humanist Reflection}

The present outline is an attempt at compiling the experiences and attainments of the Polish post-war reflection on the work of Fyodor Dostoevsky. The Russian genius was probably the only author who inspired both Polish researchers and writers alike. In the article, the author argues that interest was sparked both by the life of The Brothers Karamazov's author, and by his work, which, moreover, was often read in a biographical context. The Polish dostoevskology was developing in two strands: the émigré one, free from the pressures of censorship, and the domestic one which was subject to significant censorial restrictions up until 1989 . Despite the hindrances in the years 1956 to 1989 , there emerged many works which made an important contribution not only to Russian studies in Poland, but also to the global contemplation on Dostoevsky's work. Since the beginning of the I990s, a remarkable development of Polish dostoevskology has been taking place; ideology ceased to restrict researchers, and many studies of surprisingly differing methodologies have been conducted.

The article discusses the vast majority of Polish books devoted to the work, philosophy and philosophy of history of the author of Demons (the most important articles are also mentioned). What is more, the dynamics of dostoevskology are presented, together with its diversity of topics (studies on novel poetics originating from Bakhtin's concepts, issues of anthropology, religion, philosophy of history, ethics, the aesthetic and ideological influence of Dostoevsky on Polish and world literature). Also explored is its methodological diversity: from biographism, to Marxism, structuralism, semiotics, hermeneutics and the history of ideas. The works were very often interdisciplinary in nature. This review allowed the author to conclude that the significance of Polish research on the work of the Russian writer is defined as a symbiotic coupling of a particular 'Polish outlook' and a universal perspective.

KEywords: Polish dostoevskology, 'resonance space', the writer's worldview - the work's worldview, christology, philosophy of history 